\title{
Metode Penentuan Akad pada Transaksi Uang Elektronik
}

\author{
Sofwan Hadikusuma \\ Program Studi Ekonomi Islam, Universitas Islam Indonesia \\ Email korespondensi: sofwanh@uii.ac.id
}

\begin{abstract}
This paper is intended to explain the methods used by experts in determining the contracts used in electronic money transactions. The focus of this paper is not only on contract determination, but how a contract is embedded in electronic money transactions. This research is a qualitative research wich uses descriptive-analytic method. Data obtained from secondary sources such as books, journals, websites, and relevant documentation. The results showed that in principle, there are two methods in determining the contract in a muamalah transaction. The first method uses the editorial approach (words) which focuses on the contract words, and the second uses the substance (meaning) approach which considers the contract based on the aims and objectives of the contract as seen from the form of the agreement as well as the rights and obligations obtained by each party. Regarding the topic of discussion, it can be concluded that the determination of the contract in electronic money transactions uses a meaningful approach. That because the consideration used in determining the electronic money contract is based on the form of the transaction that occurs between the parties, not just the existing words.
\end{abstract}

Keywords: Electronic Money, Sharia, Determination of Contracts, Methods

Saran sitasi: Hadikusuma, S. (2021). Metode Penentuan Akad pada Transaksi Uang Elektronik. Jurnal Ilmiah Ekonomi Islam, 7(02), 806-815. doi: http://dx.doi.org/10.29040/jiei.v7i2.2395

DOI: http://dx.doi.org/10.29040/jiei.v7i2.2395

\section{PENDAHULUAN}

Financial Technology (Fintech) merupakan satu bentuk inovasi keuangan yang membentuk ulang struktur intermediasi keuangan dan membuat layanan keuangan menjadi lebih efisien (Leng et al., 2018). Salah satu kegunaan fintech adalah menjadikan proses layanan keuangan lebih efisien. Efisiensi ini dapat ditemukan pada, salah satunya, proses interaksi finansial antara dua pihak atau lebih tanpa harus bertatap muka secara langsung. Di sini, efisiensi nampak pada penggunaan waktu maupun cara penyelesaian transaksi. Dengan fintech, aktivitas terkait keuangan yang sebelumnya biasa menggunakan cara 'tradisional' (cash based) kini mulai dikurangi. Fintech menawarkan bentuk baru bagi layanan dunia keuangan yakni layanan transaksi nontunai (cashless).

Transaksi nontunai berarti melakukan suatu transaksi keuangan yang tidak menggunakan alat pembayaran berupa uang cash. Sebagai gantinya, uang yang dipakai dalam transaksi tersebut berupa uang elektronik. Uang elektronik dapat dipahami sebagai alat pembayaran non fisik dan nilainya berwujud data digital yang disimpan dalam media chip pada kartu uang elektronik atau perangkat keras pada komputer. Berbeda dengan cash based transaction, dengan menggunakan uang elektronik, konsumen tidak perlu membawa uang tunai untuk membayar barang atau jasa yang dibeli. Cukup menggunakan kartu uang elektronik yang diproses pada alat pemindai, dengan begitu pembayaran selesai dilakukan.

Penggunaan uang elektronik di Indonesia sudah menjadi perhatian banyak pihak, tak terkecuali Bank Indonesia. Pada tahun 2009, Bank Indonesia mengeluarkan Peraturan Bank Indonesia Nomor 11/12/PBI/2009 tentang Uang Elektronik (Electronic Money). Sebelum terbitnya peraturan tersebut, ide penggunaan uang elektronik pun sudah menyeruak. Hal itu ditandai dengan adanya sosialisasi dan kampanye penggunaan uang elektronik berbasis teknologi kartu pada tahun 2006. Ide awal penggunaan uang elektronik mulanya dicanangkan sebagai penunjang sosialisasi redenominasi uang rupiah namun lantas berkembang menjadi sebuah gerakan 
bernama Gerakan Nasional Non Tunai (GNTT) (Jati, 2015). GNTT sendiri kemudian menjadi gerakan resmi yang diusung Bank Indonesia setelah diresmikan oleh gubernur Bank Indonesia Agus D.W. Martowardojo pada Kamis, 14 Agustus 2014 di Jakarta. (www.bi.go.id)

Hingga saat ini (data Maret 2021) jumlah uang elektronik yang beredar di Indonesia berjumlah 470,811,351 yang diterbitkan oleh lebih dari tiga puluh lembaga baik bank maupun non bank. Jumlah uang elektronik yang beredar tersebut meningkat $70 \%$ dibanding peredarannya satu tahun ke belakang yang pada maret 2020 berjumlah 330.391.364. Begitu juga dengan volume transaksi uang elektronik yang mencapai 420,510,643 senilai Rp 21,420,774.89, meningkat dibanding masa satu tahun ke belakang yang hanya berjumlah 401.008.518 senilai 15.036.069,58. (www.bi.go.id)

Menyikapi perkembangan penggunaan uang elektronik yang semakin pesat sebagaimana ditunjukkan data di atas, dapat dikatakan bahwa konsumen (masyarakat Indonesia) menyambut baik inovasi tersebut, terlebih ketika melihat kemudahan yang ditawarkan pada banyak transaksi keuangan. Namun begitu, dalam kapasitas konsumen sebagai masyarakat muslim, transasksi uang elektronik perlu ditinjau dari kaca mata syariah terkait bentuk transaksi dan kesesuaiannya dengan ajaran Islam. Hal demikian tidak lain disebabkan oleh tuntutan agama yang mana setiap muslim harus menyesuaikan segala aktivitasnya dengan syariat Islam tak terkecuali dalam hal bertransaksi menggunakan uang elektronik.

Sebagai tanggapan terhadap fenomena penggunaan uang elektronik yang semakin meluas, pada tanggal 19 September 2017 Dewan Syariah Nasional-Majelis Ulama Indonesia (DSN-MUI) menerbitkan fatwa tentang uang elektronik syariah. Dalam keterangannya, fatwa ini diterbitkan berdasarkan pertimbangan penggunaan uang elektronik di Indonesia yang semakin marak dan kebutuhan masyarakat muslim Indonesia akan penjelasan ketentuan dan batasan hukum syariahnya. Terbitnya fatwa ini menjadi angin segar bagi masyarakat muslim di Indonesia secara umum dan khususnya lagi bagi kalangan akademisi maupun praktisi ekonomi Islam. Pasalnya, dengan terbitnya fatwa ini, kekhawatiran terkait keabsahan bertransaksi menggunakan uang elektronik menjadi berkurang.
Di samping penjelasan fatwa DSN-MUI, terdapat beberapa penelitian yang membahas tentang titik temu pelaksanaan transaksi uang elektronik dengan ketentuan-ketentuan Syariah. Seperti yang dilakukan oleh (Abdulfattah \& Kurniawan, 2018) dan juga (Anam, 2018) yang menganalisis (takyif) akad-akad yang digunakan dalam transaksi uang elektronik. Begitu juga dengan (Wijaya, 2018) yang lebih spesifik menganalisis penggunaan akad pada uang elektronik Go-pay dan OVO. Penelitian lain dilakukan oleh (Nengsih, 2019) dan (Alhusni \& Mustiah, 2019) membahas kesesuaian penggunaan uang elektronik dengan hukum Syariah. Selain itu, (Muamar \& Alparisi, 2017) dan (Syamsuri et al., 2020) membahas uang elektronik dari aspek kesesuaiannya dengan maqashid Syariah.

Berbeda dengan penelitian-penelitian sebelumnya, tulisan ini berfokus pada persoalan yang lebih mendasar yaitu untuk menjelaskan metodemetode yang digunakan para ahli untuk menentukan akad pada setiap transaksi muamalah, termasuk transaksi uang elektronik. Urgensi penelitian ini yaitu dengan mengetahui metode-metode itu, seseorang akan bisa memahami mengapa para ahli menetapkan akad tertentu (seperti wadi'ah, qardh, ijarah, wakalah, sharf, dll.) pada suatu transaksi uang elektronik dan diharapkan juga akan bisa menjelaskan alasan perbedaan pendapat para ahli dalam masalah ini.

\section{METODE PENELITIAN}

Penelitian ini termasuk dalam jenis penelitian kualitatif di mana proses dan makna (perspektif subyek) memiliki peran yang tampak. Sifat penelitian adalah deskriptif-analitis, yaitu dimulai dari pemaparan data-data yang ada untuk kemudian dianalisis berdasarkan teori-teori yang ada guna mendapatkan suatu kesimpulan tertentu. Data-data yang ada dikumpulkan melalui penelusuran pustaka baik berupa buku, jurnal, dokumentasi, dan sumber lain yang sesuai. Selanjutnya, data-data yang telah terkumpul dianalisis menggunakan teknik analisis isi (content analisys). Teknik analisis isi adalah teknik penelitian khusus untuk melaksanakan analisis tekstual dengan mereduksi teks menjadi unit-unit (kalimat, ide, gambar, dsb.) dan kemudian menerapkan skema pengodean pada unit-unit tersebut untuk membuat kesimpulan mengenai komunikasi dalam teks (West \& Turner, 2008). 


\section{Jurnal Ilmiah Ekonomi Islam, 7(02), 2021, 808}

\section{HASIL DAN PEMBAHASAN}

\subsection{Hasil Penelitian}

Bagian ini akan membahas tiga poin: pertama, konsep akad; kedua, metode penentuan akad; dan ketiga, penjabaran tentang uang elektronik.

a. Konsep akad

Istilah akad diserap dari bahasa Arab yang secara etimologi berarti ikatan. Sebagai istilah dalam fiqh, akad adalah pertemuan ijab dan kabul sebagai pernyataan kehendak dua pihak atau lebih untuk melahirkan suatu akibat hukum pada objeknya. Akibat hukum pada objek akad dapat berupa pemindahan kepemilikan (at-tamlik), melakukan suatu pekerjaan (al-'amal), melakukan persekutuan (al-isytirak), melakukan pendelegasian (at-tafwidh), atau melakukan penjaminan (at-tautsiq). (Anwar, 2010)

Suatu akad dianggap sah ketika memenuhi rukun dan syarat-syaratnya. Rukun akad yaitu: 'aqidani (dua pihak pelaku akad), ma'qud 'alaih (obyek akad), dan shighah (ijab dan kabul). Setelah rukun beserta syaratsyaratnya terpenuhi, mengidentifikasi bentuk kesepakatan (akad) pada suatu perjanjian dua pihak atau lebih sangatlah penting. Hal ini dikarenakan


'aqd) masing-masing. Maksud dari hukum akad (hukm al-'aqd) adalah akibat-akibat yang muncul sebagai konsekuensi dari berlakunya suatu akad sebagaimana telah ditetapkan oleh syariat (akibat hukum pokok dari perjanjian). Misalnya adalah akad jual beli yang tujuannya adalah untuk memindakkan hak kepemilikan atas suatu benda kepada pembeli dengan suatu imbalan; Pindahnya hak kepemilikan tersebut adalah hukum akad. Misal selain itu adalah pada kesepakatan sewa menyewa. Akad sewa bertujuan untuk memindahkan hak milik manfaat suatu benda dari pihak yang menyewakan kepada penyewa. Pindahnya hak milik manfaat benda tersebut, yang merupakan perwujudan dari tujuan akad adalah akibat hukum pokok akad (hukm al-'aqd) (Anwar, 2010). Dengan mengetahui jenis akad, akibat hukum berupa hak maupun kewajiban masing-masing pihak dapat ditentukan dan kemudian didistribusikan.

b. Metode penentuan akad pada suatu transaksi muamalah

Salah satu rukun akad yang mempunyai peranan penting dalam menentukan jenis akad yang berlaku pada suatu transaksi adalah shighah. Shighah dimaknai sebagai formula akad yang terdiri dari ijab dan kabul. Ijab adalah suatu pernyataan kehendak yang pertama muncul dari suatu pihak untuk melahirkan suatu tindakan hukum, yang dengan pernyataan kehendak tersebut ia menawarkan penciptaan tindakan hukum yang dimaksud di mana bila penawaran itu diterima oleh pihak lain maka terjadilah akad. Sedangkan kabul adalah pernyataan kehendak yang menyetujui ijab yang dengannya tercipta suatu akad.(Anwar, 2010)

Dari penjelasan di atas dapat dipahami bahwa esensi akad adalah bertemunya kehendak dua orang atau lebih untuk bersepakat tentang sesuatu. Kehendak tersebut mewakili kerelaan masing-masing pihak terhadap hak dan kewajiban yang timbul dari kesepakatan yang diingini tersebut. Kehendak dan kerelaan pihak yang berakad adalah unsur penting yang menentukan jenis akad beserta keabsahannya.

Kehendak untuk bersepakat dan kerelaan diri untuk menerima konsekuensi akad (hak dan kewajibannya) haruslah diungkapkan. Hal ini karena keduanya adalah perkara batin yang tidak mungkin diketahui oleh orang lain kecuali jika diungkapkan. Salah satu cara untuk menerjemahkan apa yang ada dalam diri sehingga dapat dipahami oleh orang lain adalah dengn ucapan (kata-kata).

Pembahasan ungkapan dalam ijab dan kabul serta pemahaman bahwa ungkapan tersebut merupakan cara untuk menerjemahkan keinginan dan kerelaan para pihak yang berakad menimbulkan satu polemik dalam penentuan akad. Persoalan yang muncul yaitu apakah ucapan sudah cukup mewakili kehendak diri sehingga akad yang berlaku adalah yang sesuai dengan redaksi ucapan tersebut? Ataukah diperlukan pendekatan lain selain hanya melihat kepada redaksi ucapan? Untuk memperjelas gambaran persoalan, ilustrasinya adalah sebagai berikut: jika ada pedagang yang mengatakan kepada calon pembeli untuk 'mengambil' barang dagangannya, lantas apakah boleh pembeli mengambil secara cuma-cuma atau haruskah ia membayar? Jika berpegang pada ketentuan bahwa ucapan adalah terjemahan dari keinginan dan kerelaan diri, maka pembeli dapat mengambil barang tersebut secara cuma-cuma. Karena kata 'ambil' dapat dimaknai sebagai pemberian secara gratis sehingga akad yang terjadi adalah hibah, bukan jual beli.

Walaupun ucapan dianggap sebagai penerjemah keinginan dalam diri, bukan berarti para ahli fiqh sepakat bahwa akad ditentukan berdasarkan redaksi ucapan yang diungkapkan oleh para pihak yang berakad. Pada permasalahan ini, setidaknya ada dua pendapat yang masing-masing mewakili macam 
pendekatan tertentu dalam menentukan akad, yaitu pendekatan redaksi (lafaz) dan substansi (makna).

1) Pendekatan redaksi (lafaz)

Pendekatan lafaz adalah metode untuk menentukan akad suatu transaksi yang mendasarkan penentuannya pada bentuk/bunyi redaksi kata yang diungkapkan pihak yang berakad. Dengan metode ini, akad ditentukan berdasarkan apa yang diucapkan oleh pelaku akad tanpa mempertimbangkan niat atau maksud yang mungkin terkandung dari ucapan tersebut.

Di antara ahli fiqh yang menggunakan metode ini adalah Imam Syafi'i ra. Imam Syafi'i merujuk kepada redaksi akad (dzahir al-alfaz) dalam menentukan suatu akad berikut konsekuensi yang muncul (Zahrah, 1996). Landasan argumentatif penggunaan metode ini adalah kaidah yang menyatakan bahwa dalam syariat Islam suatu amalan dihukumi berdasarkan pada hal-hal yang nampak (dzahir) saja, sedangkan hal-hal yang tidak tampak (batin), urusannya diserahkan kepada Allah swt. Perkara niat adalah perkara batin, oleh karenanya, urusannya diserahkan kepada Allah swt. (Mughits, 2017).

Terdapat beberapa dalil yang menguatkan pendapat ini, di antaranya yaitu dalil-dalil yang menerangkan bahwa manusia tidak dibebankan untuk mengetahui sesuatu yang bersifat bathiniyah melainkan hanya diperintah untuk menghukumi yang lahir/tampak saja. Salah satunya adalah apa yang diterangkan dalam surat Al-Isra' ayat 36:

$$
\text { وَلاَ تَقْفُ مَا لَيْسَ لَكَ بِهِ عِلْمُ }
$$

Janganlah kamu mengikuti apa yang kamu tidak mempunyai pengetahuan tentangnya.

Wajhu ad-dalalah dari ayat ini yaitu bahwa Allah swt. tidak menjadikan manusia bisa mengetahui niat orang lain sehingga bisa menghukuminya dalam perkara dunia. Sebagai makhluk, manusia hanya bisa menghukumi aspek lahiriyah saja. Oleh karena itu, penilaian ataupun penghukuman terhadap niat orang lain termasuk hal yang dilarang sebagaimana dititahkan dalam ayat karena manusia tidak mempunyai ilmu/pengetahuan tentangnya.

Dalil lain yang menguatkan pendapat ini yaitu hadis yang diriwayatkan oleh Imam Bukhari ra.:



Rasulullah shallallahu 'alaihi wasallam bersabda: Aku tidak diperintah untuk menyelidiki hati seseorang atau mengetahui isi perutnya. (HR. Bukhari)

Wajhu ad-dalalah dari hadis ini yaitu bahwa niat seseorang dalam melakukan suatu perbuatan adalah perkara batin yang tidak diketahui kecuali oleh Allah swt. Manusia tidak diperintah untuk mencari tahu sebagaimana Rasulullah saw. yang menyatakan bahwa ia tidak diperintah untuk menyelidiki isi hati seseorang. Sebagai hasilnya, manusia hanya diperintah untuk menyelidiki halhal yang lahir atau tampak saja.

2) Pendekatan substansi (makna)

Pendekatan substansi adalah metode untuk menentukan akad suatu transaksi yang mempertimbangkan niat dan maksud pelaku akad. Dengan metode ini, akad ditentukan berdasarkan niat dan maksud pelaku akad yang ditafsirkan dari redaksi akad berdasarkan indikator-indikator (qara'in) yang menunjukkan adanya niat dan maksud tersebut.

Pendekatan ini merupakan metode yang digunakan oleh mayoritas (jumhur) ahli fiqh seperti ulama mazhab hanafi, maliki, hanbali. Para pendukung pendapat ini tidak menggunakan konotasi verbal (dalalah lafziyah) semata dalam menentukan akad, melainkan juga melihat kepada maksud pelaku akad selama ada indikatorindikator yang menunjukkan hal tersebut. Landasan argumentatif pendekatan ini adalah bahwa ungkapan kata-kata sebenarnya tidak memiliki kemampuan untuk menciptakan akad kecuali jika ungkapan itu memang mewakili kehendak yang ada dalam diri (Zahrah, 1996). Pada prinsipnya, hal terpenting dalam penciptaan akad adalah kehendak para pelaku akad. Oleh karenanya, jika ada hal-hal yang mengindikasikan adanya kehendak pelaku akad dalam suatu transaksi maka harus dipertimbangkan dalam upaya menentukan jenis akad transaksi tersebut.

Dalil yang menguatkan pendapat ini antara lain hadis tentang niat yang diriwayatkan oleh Imam Bukhari ra.: 


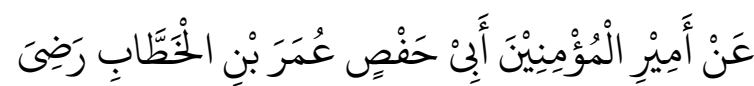



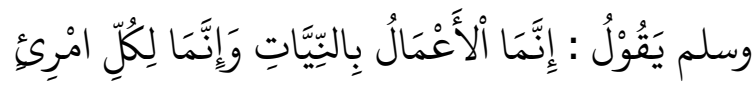
مَانَوَى

Dari Amirul Mukminin Abu Hafsh Umar bin Khaththab ra. Berkata, aku mendengar Rasulullah saw. bersabda: "Sетиa amal perbuatan tergantung niatnya dan setiap orang akan mendapatkan sesuai apa yang diniatkan." (HR. Bukhari)

Wajhu ad-dalalah dari hadis ini adalah bahwa segala hal tidak dihukumi kecuali berdasarkan niat yang ada. Hadis ini menjelaskan bahwa hukum suatu perbuatan tidaklah dilihat dari bentuk lahirnya saja melainkan maksud dari dilakukannya perbuatan tersebut. Ketentuan ini berlaku umum sebagaimana juga berlaku khusus pada transaksi muamalah (akad). Oleh karena itu, setiap hal yang bisa menunjukkan adanya niatan pelaku akad haruslah dijadikan pertimbangan ketika ingin menghukumi akad tersebut tanpa berhenti pada redaksi semata.

c. Transaksi Uang elektronik

Merujuk pada Peraturan Bank Indonesia Nomor 11/12/PBI/2009 tentang Uang Elektronik (Electronik Money), yang dimaksud uang elektronik adalah alat pembayaran yang memenuhi unsur-unsur: a) diterbitkan atas dasar nilai uang yang disetor terlebih dahulu oleh pemegang kepada penerbit; b) nilai uang disimpan secara elektronik dalam suatu media seperti server atau chip; c) digunakan sebagai alat pembayaran kepada pedagang yang bukan merupakan penerbit uang elektronik tersebut; dan d) nilai uang elektronik yang disetor oleh pemegang dan dikelola oleh penerbit bukan merupakan simpanan sebagaimana dimaksud dalam undang-undang yang mengatur mengenai perbankan.

Definisi lain tentang uang elektronik didapat dari publikasi yang diterbitkan oleh Bank for International Settlement tahun 1996. Dalam publikasi tersebut, dinyatakan bahwa produk uang elektronik adalah "stored-value or prepaid products in which a record of the funds or value available to a consumer is stored on an electronic device in the consumer's possession" (Bank for International Settlements, 1996).

Dua definisi uang elektronik di atas memberikan pemahaman bahwa uang elektronik adalah jenis uang nontunai yang nilainya disimpan pada suatu media. Uang itu dapat digunakan sebagai alat pembayaran kepada pedagang yang telah bekerjasama dengan pihak penerbit dengan cara menyentuhkan media penyimpan pada mesin pembaca/pemroses transaksi uang elektronik. Jadi pada hakikatnya, uang elektronik adalah uang tunai tanpa fisik (cashless money) yang nilainya didasarkan atas uang fisik yang disetor terlebih dahulu oleh pemegang kepada penerbit, atau adalah uang tunai yang dikonversi menjadi data elektronik dan selanjutnya nilai tersebut disimpan dalam media chip pada kartu atau harddisk pada komputer yang dengan begitu kemudian dapat digunakan sebagai alat pembayaran (Usman, 2017).

Transaksi uang elektronik berarti segala transaksi yang melibatkan penggunaan uang elektronik sebagai obyek maupun perantara. Secara umum, ada tiga jenis transaksi uang elektronik, yaitu penerbitan dan pengisian, pembayaran, dan deposit. (Hidayati et al., 2006)

1) Transaksi Penerbitan (issuance) dan Pengisian (top-up)

Aktivitas transaksi uang elektronik dimulai dari penerbitan media penyimpanan (oleh pihak penerbit) yang akan difungsikan untuk menyimpan nilai uang elektronik. Media tersebut ada yang berbasis chip (dalam kartu) atau berbasis server (dalam perangkat komputer atau gawai). Setelah penerbitan, proses selanjutnya adalah pengisian saldo uang elektronik. Pada media berupa kartu, pihak penerbit biasanya sudah mengisikan uang elektronik terlebih dahulu pada kartu yang akan dijual kepada pihak konsumen. Sedangkan pada media berbasis server, uang elektronik diisi berdasar konversi uang tunai yang disetor oleh pengguna dan nilainya disimpan dalam perangkat keras pada komputer atau gawai. Jika kemudian saldo uang elektronik dari pengisian pertama sudah habis, pengguna akan melakukan pengisian ulang (top-up) dengan menyetor sejumlah uang kepada penerbit untuk kemudian dikonversi menjadi uang elektronik.

2) Transaksi Pembayaran

Fungsi keberadaan uang elektronik pada intinya adalah untuk kebutuhan transaksi pembayaran. Uang elektronik menggantikan peran uang tunai untuk digunakan sebagai alat pembayaran barang atau jasa. Dengan menggunakan uang elektronik, transaksi antar pihak tidak lagi harus menggunakan cara 
tradisional yang mengharuskan tatap muka atau dilakukan membawa uang tunai.

3) Refund

Refund berarti menukarkan kembali nilai uang elektronik untuk dikonversikan menjadi uang sebagaimana biasa. Pengguna uang elektronik bisa melakukan refund pada saat ingin mengakhiri penggunaan uang elektronik dan masih tersisa saldo di media penyimpanan yang dimilikinya atau pada saat masa berlaku media penyimpanan uang elektronik tersebut sudah berakhir (Muamar \& Alfarisi, 2017).

\subsection{Pembahasan}

Sebelum mengetahui pendekatan apa yang digunakan para ahli untuk menentukan akad uang elektronik, akan dibahas terlebih dahulu analisis fiqh (takyif fiqhi) pada penggunaan akad untuk setiap transaksi uang elektronik.

a. Akad-akad pada transaksi uang elektronik

Merujuk kepada fatwa DSN-MUI tentang uang elektronik syariah, dapat disimpulkan bahwa akad untuk setiap transaksi uang elektronik adalah sebagai berikut:

1) Transaksi penerbitan dan pengisian ulang (top-up)

Transaksi penerbitan dan pengisian ulang uang elektronik terjadi antara pihak penerbit dan pengguna. Fatwa DSN-MUI tentang uang elektronik menyatakan bahwa akad yang berlaku antara penerbit dengan pengguna adalah wadi'ah atau qardh. Pada fatwa tersebut dijelaskan ketentuan dan batasan-batasan masing-masing akad. Satu hal yang tidak tercantum dalam fatwa tersebut adalah penjelasan mengenai bagaimana transaksi uang elektronik tersebut bisa disimpulkan menggunakan akad wadi'ah atau qardh. Oleh karena itu, berikut akan dipaparkan penjelasan singkat terkait dua akad tersebut dalam kaitannya dengan transaksi antara penerbit dan pengguna.

a) Transaksi uang elektronik menggunakan akad wadi'ah

Secara sederhana, wadi'ah diartikan sebagai titipan. Dalam pembahasan fiqh muamalah, secara terminologi, merujuk kepada pendapat kelompok mayoritas ulama (Syafi'iyah dan Malikiyah), akad wadi'ah berarti suatu bentuk perwakilan untuk menjaga suatu barang kepemilikan dengan cara tertentu.(AzZuhayli, n.d.) Wadi'ah termasuk ke dalam kategori akad jaiz, amanah, dan tabarru' (kebalikannya yaitu lazim, dhamanah, dan tijari). Konsekuensinya, akad dapat diterminasi kapan saja tanpa harus menunggu persetujuan pihak lain, berbasis saling percaya dan tolong-menolong.

Dalam fatwa dijelaskan beberapa ketentuan akad wadi'ah dalam kaitannya dengan kegiatan transaksi uang elektronik, yaitu:

(1) Jumlah nominal uang elektronik bersifat titipan yang dapat diambil/digunakan oleh pemegang kapan saja;

(2) Jumlah nominal uang elektronik yang dititipkan tidak boleh digunakan oleh penerima titipan (penerbit), kecuali atas izin pemegang kartu;

(3) Dalam hal jumlah nominal uang elektronik yang dititipkan digunakan oleh penerbit atas izin pemegang kartu, maka akad titipan (wadiah) berubah menjadi akad pinjaman (qardh), dan tanggung jawab penerima titipan sama dengan tanggung jawab dalam akad qardh.

(4) Otoritas terkait wajib membatasi penerbit dalam penggunaan dana titipan dari pemegang kartu (dana float).

(5) Penggunaan dana oleh penerbit tidak boleh bertentangan dengan prinsip syariah dan peraturan perundangundangan.

Selanjutnya, analisis penerapan akad wadi'ah pada transaksi uang elektronik dipaparkan sebagai berikut:

(1) Identifikasi rukun akad wadi'ah.

Rukun akad wadi'ah menurut jumhur ulama ada empat, yaitu dua pihak yang berakad (penitip dan yang dititipi), barang titipan, dan shighah akad (ijab dan qabul) (Az-Zuhayli, n.d.). Dalam transaksi uang elektronik, dua pihak yang berakad adalah penerbit dan pengguna, kemudian barang titipan (obyek akad) adalah uang yang disetor pengguna kepada penerbit, dan shighat adalah persetujuan masing-masing pihak yang untuk berakad.

(2) Mekanisme akad wadi'ah pada transaksi uang elektronik.

Setelah mengidentifikasi rukun wadi'ah, dapat digambarkan bahwa ketika 


\section{Jurnal Ilmiah Ekonomi Islam, 7(02), 2021, 812}

pengguna menyerahkan sejumlah uang tunai kepada pihak Penerbit, pengguna dianggap menitipkan uangnya tersebut kepada Penerbit. Sebagai tanda adanya uang yang dititipkan kepadanya, Penerbit memberi bukti penitipan yaitu nilai uang elektronik yang disimpan pada media chip (kartu) atau server (gawai).

(3) Analisis penerapan akad wadi'ah pada transaksi uang elektronik.

Akad wadi'ah termasuk dalam kategori akad amanah. Maksud dari akad amanah adalah bahwa harta yang berada pada pihak penerima titipan merupakan amanah yang harus dijaga untuk kepentingan pemiliknya. Oleh karena itu pihak yang dititipi tidak bertanggung jawab terhadap musibah yang menimpa barang titipan kecuali ada unsur kelalaian dalam menjaganya (Kementrian Wakaf dan Urusan Agama Kuwait, n.d.). Obyek wadi'ah adalah barang yang harus dijaga dan tidak boleh digunakan oleh pihak yang dititipi. Pada obyek wadi'ah berbentuk benda (selain uang), ketentuan tersebut mudah dilakukan. Namun jika obyeknya adalah uang, ketentuan tersebut dirasa sulit dipenuhi. Alasannya, menjaga obyek wadi'ah adalah menjaga wujudnya ('ain) bukan nilainya (qimah).

b) Transaksi uang elektronik menggunakan akad qardh

Akad qardh, menurut pendapat yang banyak dikenal luas di kalangan para fuqahâ Hanafiyah, berarti sesuatu yang diberikan kepada orang lain untuk dikembalikan lagi seperti sedia kala. Sedangkan menurut mazhab-mazhab yang lain, qardh berarti memberikan sesuatu kepada orang lain dengan mensyaratkan pengembalian seperti barang yang diberikan (Al-Masry, 2001). Dalam fatwa dicantumkan beberapa ketentuan qardh dalam kaitannya dengan kegiatan transaksi uang elektronik, yaitu:

(1) Jumlah nominal uang elektronik bersifat utang yang dapat diambil/digunakan oleh pemegang kapan saja.

(2) Penerbit dapat menggunakan (menginvestasikan) uang utang dari pemegang uang elektronik.
(3) Penerbit wajib mengembalikan jumlah pokok piutang Pemegang uang elektronik kapan saja sesuai kesepakatan;

(4) Otoritas terkait wajib membatasi penerbit dalam penggunaan dana pinjaman (utang) dari pemegang kartu (danafloat).

(5) Penggunaan dana oleh penerbit tidak boleh bertentangan dengan prinsip syariah dan peraturan perundangundangan.

Selanjutnya, penerapan akad qardh pada transaksi uang elektronik penjelasannya adalah sebagai berikut:

(1) Identifikasi rukun akad qardh.

Rukun akad qardh menurut jumhur, sebagaimana umumnya rukun akad, adalah adanya dua pihak yang bersepakat, adanya obyek akad, dan shighat (ijab kabul). Apabila diterapkan pada transaksi uang elektronik, maka Penerbit dan pihak pengguna adalah dua pihak yang berakad, uang yang disetor pengguna kepada Penerbit adalah obyek akad, dan persetujuan masing-masing pihak yang untuk berakad adalah shighahnya.

(2) Mekanisme akad qardh pada transaksi uang elektronik.

Terjadinya akad qardh pada transaksi uang elektronik digambarkan dengan uang yang disetor konsumen kepada pihak penerbit dianggap sebagai utang yang harus dikembalikan nantinya. Artinya, seketika menerima setoran uang tunai dari pengguna maka penerbit dianggap berutang kepada pengguna. Sebagai tanda adanya utang, Penerbit memberi bukti berupa nilai uang elektronik yang disimpan pada media chip (kartu) atau server (komputer/gawai).

(3) Analisis penerapan akad qardh pada transaksi uang elektronik.

Berbeda dengan qardh, kepemilikan harta pada akad wadi'ah tidak berpindah dari penitip kepada pihak yang dititipi, sedangkan dalam qardh kepemilikan harta berpindah kepada pihak yang berutang (muqtaridh). Dalam hal penggunaan dan pemanfaatan barang, hal itu tidak diperbolehkan pada obyek akad 


\section{Jurnal Ilmiah Ekonomi Islam, 7(02), 2021, 813}

wadî'ah, sebaliknya diperbolehkan pada obyek akad qardh (Al-Masry, 2001). Konsekuensi dari ketentuan ini adalah bahwa obyek akad transaksi uang elektronik dengan akad qardh, yaitu uang yang disetor pengguna kepada pihak Penerbit, dapat dikelola/digunakan lebih lanjut, termasuk mencampurnya dengan barang-barang lain. Demikian itu berarti pihak Penerbit hanya dibebankan untuk menjaga nilai uangnya (qimah) saja, bukan wujud fisiknya ('ain).

2) Transaksi pembayaran

Transaksi pembayaran menggunakan uang elektronik terjadi antara pengguna dengan merchant (pedagang atau penyedia jasa). Dalam praktiknya, setelah pengguna membeli atau menyewa jasa suatu obyek tertentu, dia akan membayar menggunakan uang elektronik. Oleh karena uang elektronik hanya berperan sebagai alat pembayaran, maka jika obyeknya adalah barang maka akad yang terjadi adalah jual beli (bay'), namun jika obyeknya adalah jasa maka akad yang terjadi adalah sewa (ijarah).

3) Refund

Refund bisa dimaknai sebagai terminasi akad. Pengguna yang melakukan refund dianggap mengakhiri akad sehingga dana yang diterima merupakan dana wadi'ah atau qardh yang dikembalikan.

b. Penentuan jenis akad pada transaksi uang elektronik

Dalam fatwanya tentang uang elektronik, DSNMUI menyebutkan beberapa akad yang berlaku pada transaksi uang elektronik seperti wad'iah, qardh, ijarah, ju'alah, dan wakalah bil-ujrah. Setiap akad tersebut mewakili bentuk transaksi yang terjadi baik antara penerbit dengan pemegang (wadi'ah atau qardh), penerbit dengan pihak penyelenggara, termasuk merchant (ijarah, ju'alah, dan wakalah bilujrah), dan penerbit dengan agen layanan keuangan digital (ijarah, ju'alah, dan wakalah bil-ujrah).

Salah satu persoalan yang muncul dalam masalah penentuan akad pada suatu transaksi adalah terkait ijab dan qabul. Pada transaksi uang elektronik tidak ada ijab qabul yang dinyatakan dengan jelas (sharih) bahwa transaksi antar pihak adalah menggunakan akad wadi'ah, qardh, ijarah, ju'alah, atau wakalah bilujrah. Ketika pengguna ingin melakukan pengisian, misalnya, dia tidak mengatakan kepada pihak penerbit bahwa dia akan melakukan akad wadi'ah ataupun qardh. Lalu bagaimana kemudian transaksi antar mereka dikatakan menggunakan akad-akad tersebut?

Selain dengan ucapan, ijab dan kabul memang juga bisa diungkapkan dengan tulisan ataupun isyarat yang dipahami para pihak yang bertransaksi (Zahrah, 1996). Pada perkembangannya, terkadang ijab dan kabul dalam suatu transaksi dilakukan tanpa kata-kata, tulisan, ataupun isyarat sama sekali. Hal itu merupakan buah adaptasi terhadap perkembangan teknologi yang semakin maju (Ridwan, 2017). Para ahli menyebut transaksi tersebut terlaksana dengan atta'athi. At-ta'athi yaitu pernyataan kehendak seorang pelaku akad yang ditandai dengan perbuatan yang bisa dipahami dari perbuatan tersebut bahwa orang tersebut ingin melakukan dan menyelesaikan suatu transaksi (Anwar, 2010).

Dari beberapa cara pengungkapan kehendak, bisa diidentifikasi bahwa shighah yang dipakai pada transaksi uang elektronik dapat berupa ucapan, tulisan, dan juga ta'athi. Shighah dengan ucapan terjadi pada saat pengguna ingin mengisi saldo uang elektronik dengan mengungkapkan keinginannya tersebut dengan ucapan langsung kepada pihak penerbit atau agen; shighah dengan tulisan terjadi pada saat pengguna mengisi saldo uang elektronik atau melakukan pembayaran melalui perangkat elektronik (gawai); sedangkan shighah dengan atta'athi terjadi ketika pengguna kartu melakukan pembayaran dengan cara menyentuhkan kartu pada alat pemindai pembayaran milik merchant.

Perlu diperhatikan sekali lagi bahwa dari tiga kemungkinan shighat yang digunakan dalam transaksi uang elektronik, tidak ada redaksi yang jelas menyebut akan adanya pelaksanaan akad wadi'ah, qardh, jual beli, sewa, dll. Ketiga shighat tersebut dinyatakan dengan pernyataan maupun perbuatan yang menjelaskan terjadinya akad tanpa menyebut nama akad. Dari gambaran transaksi tersebut, dapat dikatakan bahwa akad-akad yang berkenaan dengan transaksi uang elektronik ditentukan melalui pendekatan substansi (makna). Hal itu karena walaupun beberapa transaksi ada yang menggunakan ucapan dalam shighat-nya, namun ucapan tersebut dianggap tidak cukup untuk dijadikan dasar penentuan akad. Alasannya adalah karena ucapan yang diungkapkan memiliki kemungkinan mengandung maksud lain selain maksud yang dipahami secara bahasa sehingga tidak bisa berhenti dipahami dari ucapan itu semata. Kemungkinan adanya maksud lain 
tersebut bisa diketahui dari kebiasaan ('urf) yang berlaku. Kaidahnya adalah 'urf bisa berlaku sebagai sandaran hukum (al-'âdah muhakkamah). Dengan begitu, ucapan yang diungkapkan pelaku akad bisa dimaknai lebih jauh dan diketahui maksudnya untuk kemudian dijadikan pertimbangan penentuan jenis akadnya.

\section{KESIMPULAN}

Perhatian para ahli hukum Islam terhadap uang elektronik berkisar pada penentuan jenis akad dan bagaimana kesesuaian pelaksanaan transaksi uang elektronik dengan ketentuan syariah. Dalam menentukan akad, ada dua metode yang digunakan yaitu metode yang menggunakan pendekatan redaksi dan metode yang menggunakan pendekatan substansi. Transaksi uang elektronik dengan berbagai macam bentuknya disimpulkan menggunakan pendekatan substansi. Alasannya adalah karena para ahli mendasarkan penentuannya pada pertimbangan bentuk transaksi, bukan redaksi (lafaz) semata. Konsekwensi dari pendekatan ini adalah bahwa suatu redaksi atau istilah tertentu dianggap masih belum cukup untuk menyatakan kehendak pelaku akad. Indikator-indikator lain yang turut dianggap mendukung pemahaman adanya suatu kehendak akad juga harus ditelusuri sehingga pelaksanaan akad bisa dilakukan secara benar menurut syariat.

\section{UCAPAN TERIMA KASIH}

Ucapan terima kasih penulis haturkan kepada teman-teman di Program Studi Ekonomi Islam UII yang telah bersedia meluangkan waktunya untuk menjadi partner diskusi sehingga penulis bisa mendapatkan banyak insight terkait dengan topik pembahasan tulisan ini.

\section{REFERENSI}

Abdulfattah, M. R. W., \& Kurniawan, R. R. (2018). Uang Elektronik Dalam Perspektif Islam. JURNAL EKONOMI DAN PERBANKAN SYARIAH, 6(1), 90-106. https://doi.org/10.46899/jeps.v6i1.89

Alhusni, \& Mustiah. (2019). Tinjauan Hukum Islam tentang Penggunaan Uang Elektronik dan Relevansinya Terhadap Lahirnya Fatwa Dewan Syariah Nasional Majelis Ulama Indonesia. Nurani: Jurnal Kajian Syari'ah Dan Masyarakat, $\quad$ 19(1), 1-14. https://doi.org/10.19109/nurani.v19i1.2864
Al-Masry, R. Y. (2001). Al-Jami' fi Ushul ar-Riba. Dar el-Qalam.

Anam, C. (2018). E-Money (Uang Elektronik) dalam Perspektif Hukum Syari'ah. Qawãnïn: Journal of Economic Syaria Law, 2(1), 95-112. https://doi.org/10.30762/q.v2i1.1049

Anwar, S. (2010). Hukum Perjanjian Syariah. Rajawali Pers.

Az-Zuhayli, W. (n.d.). Al-Fiqh al-Islami wa Adillatuhu. Dar al Fikr.

Bank for International Settlements. (1996). Implications for central banks of the development of electronic money. Bis, October, 1.

Hidayati, S., Nuryanti, I., Firmansyah, A., Fadly, A., Darmawan, \& Yuwana, I. (2006). Kajian Operasional E-Money. Bank Indonesia, 1-60.

Jati, W. R. (2015). Menakar Mode Konsumerisme Baru Kelas Menengah Indonesia. Journal of Sosioteknologi, 14(2), 102-111. https://doi.org/10.1017/CBO9781107415324.00 4

Kementrian Wakaf dan Urusan Agama Kuwait. (n.d.). Al-Mawsu'ah al-Fiqhiyyah al-Kuwaytiyyah.

Leng, S. Y., Talib, A., \& Gunardi, A. (2018). Financial Technologies: A Note on Mobile Payment. Jurnal Keuangan Dan Perbankan, 22(1), 51-62. https://doi.org/10.26905/jkdp.v22i1.1993

Muamar, A., \& Alparisi, A. S. (2017). Electronic money (e-money) in maqashid al-sharia perspective. Journal of Islamic Economics Lariba, 3(2), 75-84.

Mughits, A. (2017). Penerapan Prinsip at-Taradi dalam Akad-akad Muamalat. Aplikasia: Jurnal Aplikasi Ilmu-Ilmu Agama, 17(1), 49-61. https://doi.org/10.14421/aplikasia.v17i1.1377

Nengsih, N. (2019). Analisis Terhadap Fatwa Dewan Syariah Nasional Majelis Ulama Indonesia (DSN-MUI) Tentang Uang Elektronik Syariah (Studi Kartu Flazz BCA, Go-Pay, dan Grab-Pay). JURISDICTIE, $\quad 10(1), \quad$ 56-77. https://doi.org/10.18860/j.v10i1.6594

Ridwan, R. (2017). Rekonstruksi Ijab dan Kabul dalam Transaksi Ekonomi Berbasis Online. AlManahij: Jurnal Kajian Hukum Islam, 11(2), 175-188.

https://doi.org/10.24090/mnh.v11i2.1294

Syamsuri, Kamaluddin, I., \& Ahmad, H. F. (2020). EMoney Perspektif Maqoshid Syari'ah. Investi, 2(02), 74-86. 
Jurnal Ilmiah Ekonomi Islam, 7(02), 2021, 815

Usman, R. (2017). Karakteristik uang elektronik dalam sistem pembayaran. Yuridika, 32(1), 134166.

West, R., \& Turner, L. H. (2008). Pengantar Teori Komunikasi: Analisis dan Aplikasi. Salemba Humanika.
Wijaya, H. (2018). Takyīf Fiqh Pembayaran Jasa Transportasi Online Menggunakan Uang Elektronik (Go-Pay dan OVO). NUKHBATUL 'ULUM: Jurnal Bidang Kajian Islam, 4(2), 187203. https://doi.org/10.36701/nukhbah.v4i2.46

Zahrah, M. A. (1996). Al-Milkiyyah wa Nadzariyyatu al- 'Aqd fi asy-Syari'ah al-Islamiyah. Dar el Fikr el Arab. 